\title{
Socjotechnika lęku - zastosowanie w XXI wieku
}

Btogostawiony, kto się boi Pana.

Psalm 128 responsoryjny (Liturgia słowa)

\begin{abstract}
Streszczenie: Sterowanie ludzkimi masami za pomocą kształtowania poziomu lęku znane jest od tysięcy lat. Zmiana stymulatorów lęku w ciągu ostatnich dekad nie oznacza odejścia od podstawowej zasady socjotechnicznej mówiącej, iż system sterowany utrzymywany w stanie pobudzenia lękowego jest bardziej podatny na wpływ. Współcześnie, środki masowego przekazu, których funkcjonowanie w warunkach globalizacji wpisuje się w tzw. logikę medialną, potrafią ów mechanizm wykorzystywać sprawniej, niż kiedykolwiek. Jednocześnie współtworzą one - zapewne tylko po części świadomie - charakterystyczny dla socjotechniki proces reprodukcji porządku społecznego, którego cele zdeterminowane są interesami systemu społecznego.
\end{abstract}

Słowa kluczowe: lęk, socjotechnika, logika medialna

G łównym celem rozważań prezentowanych w artykule jest wskazanie na aktualność zastosowania intensyfikacji lęku jako mechanizmu podporządkowywania sobie ludzi. Autor stara się udzielić odpowiedzi na dwa pytania. Po pierwsze, dlaczego pomimo wypracowania demokratycznych form sprawowania władzy, pobudzanie lęku wciąż okazuje się skutecznym sposobem wywierania wpływu oraz po drugie, dlaczego nowoczesne środki masowego przekazu tak chętnie uczestniczą w tych działaniach? Wnioski płynące z analizy wskazują, iż socjotechniczna zasada, zgodnie z którą system sterowany utrzymywany w stanie pobudzenia lękowego jest bardziej podatny na wpływ nabiera współcześnie nowego wymiaru m.in. ze względu na niespójność celów reprodukcji porządku społecznego. Zwiększa to jeszcze bardziej rolę środków masowego przekazu, które mechanizm intensyfikacji lęku wykorzystują, kierując się własnymi interesami rynkowymi. Artykuł ma charakter teoretyczny, powstał w oparciu o analizę krytyczną publikacji z zakresu socjotechniki oraz prakseologii i został egzemplifikowany przypadkami zastosowania socjotechniki lęku w XXI wieku.

\section{Intensyfikacja lęku jako mechanizm socjotechniki}

Wzrost znaczenia socjotechnicznego wpływu opartego na lęku w dużym stopniu jest efektem procesu globalizacji. Jego kulturowe wyznaczniki wpływają na osłabienie poczucia wspólnotowości, co także zwiększa obawę przed samotnością i odrzuceniem. Lęk i strach są jednak (i zawsze były) immanentną cechą ludzkiej natury. Montaigne pisał 
„nie wiem zgoła, przez jakie sprężyny działa w nas strach, ale to pewna, że jest to bardzo osobliwe uczucie, toż powiadają lekarze, iż nie istnieje żadne inne, które by bardziej wytrącało nasz umysł z przyrodzonej równowagi” (Montaigne, 1985, s. 197). Współczesna wiedza psychologiczna o wpływie strachu na nasze działania jest daleko bardziej precyzyjna niż to sobie wyobrażał Montaigne, dlatego też obecnie można skuteczniej wykorzystywać instrumentalnie tę emocję do sterowania ludzkimi umysłami. W terminologii socjotechnicznej tezę o większej podatności na wpływ przedmiotu odczuwającego podwyższony stopień lęku można sformułować następująco: System sterowany utrzymywany $w$ stanie pobudzenia lękowego jest bardziej podatny na wpływ. Ujęcie tradycyjne socjotechniki, pochodzące ze szkoły Adama Podgóreckiego, obejmowało jednak tylko ten wpływ społeczny, który stanowiłby efekt świadomego działania podmiotu ${ }^{1}$. Pojęcie socjotechniki miałoby więc dotyczyć tych procesów życia społecznego, do których powstania przyczyniły się celowe działania stymulujące. Taka sytuacja dominuje z pewnością w obszarze uprawiania socjotechniki w skali konkretnego systemu społecznego (mikro). Bywa również tak, iż zachodzące zmiany, są w gruncie rzeczy ubocznym i niekoniecznie pożądanym efektem, trudno więc mówić o ich celowości. W socjotechnice w skali kultury ponadnarodowej (makro) przekształcenia społeczne rzadko stanowią efekt oddziaływania konkretnego podmiotu socjotechnicznego, znacznie częściej będąc konsekwencją oddziaływania wielu czynników, z których niektórym, ze względu na brak świadomości, nie można przypisać charakteru podmiotowego (Pawełczyk, 2000, s. 97-101). W kontekście analizy intensyfikacji lęku nie używam więc określenia metoda socjotechniczna (co nakazywałoby ujawnić podmiot stosujący ją), lecz mechanizm, co - oprócz celowych działań systemów sterujących - dopuszcza możliwość stymulacji lękowej bez pełnej świadomości współuczestniczenia w tym mechanizmie.

Na potrzeby prowadzonych $w$ tym artykule rozważań przyjmuję, iż socjotechnikę należy uznać za zbiór mechanizmów umożliwiających reprodukcję porządku społecznego w systemowo pożądanym kierunku. Niclas Luhmann wskazywał, iż system składa się ze stałych elementów i zmienia się tylko ich porządek (Luhmann, 2007, s. 23). Poczucie lęku zapewnia stabilność w znaczeniu globalnym i wiąże się nierozerwalnie z reprodukcją tego systemu (Wieczorek-Orlikowska, 2016, s. 332). W procesie socjotechnicznym mogą uczestniczyć obiekty nieposiadające wiedzy o jego przebiegu (jednostki w określonych rolach społecznych, instytucje takie jak: edukacja, wymiar sprawiedliwości, środki masowego przekazu, związki wyznaniowe itd.). Co w takim razie oznacza określenie „systemowo pożądany kierunek"? Uważam, iż wyznaczają go cele funkcjonalne wobec systemu społecznego, zapewniające mu trwałość, sprawność, efektywność, a przede wszystkim legitymizację. Proces socjotechniczny może zatem odbywać się jakby mimowolnie. Widzimy jego przebieg, zauważamy skutki, lecz nie jesteśmy w stanie zidentyfikować systemu sterującego ${ }^{2}$. W skali makro dotyczyć to może reprodukcji

${ }^{1}$ Patrz: A. Podgórecki, Zasady socjotechniki, Warszawa 1966; tegoż: Patologia życia społecznego, Warszawa 1969; prace zbiorowe pod redakcją tegoż: Socjotechnika. Jak oddziaływać skutecznie, Warszawa 1970 oraz Socjotechnika. Style działania, Warszawa 1972.

${ }^{2}$ Menager koncernu McDonald's odpowiedzialny za poszerzanie rynku zbytu np. w Azji Płd. Wsch. nie musi być świadomy, iż uczestniczy także w procesie globalizacji kultury. Benjamin Barber pisał, iż globalizującym się światem konsumpcji kieruje automatyczny pilot, którego kurs został ustawiony na zysk. Myślę, że ową tezę można odnieść także do innych sfer życia. 
ideologicznej nadbudowy czy kierunku zmian zachodzących w obrębie ponadnarodowej kultury. Należy także zauważyć, iż w warunkach współczesnej demokracji liberalnej liczba podmiotów będąca w stanie zarządzać lękiem na poziomie ogólnospołecznym jest bardzo duża i nie ogranicza się do urządzeń instytucyjnych władzy. Te ostatnie posiadają oczywiście uprzywilejowaną pozycję - wynikającą ze struktury systemu politycznego - umożliwiającą im kształtowanie świadomości zbiorowej (Porębski, 2016, s. 72). Powoduje to częste utożsamianie socjotechniki z socjotechniką polityczną. Jednostki znacznie częściej mają świadomość wywierania na nie politycznego wpływu aniżeli efektów procesów reprodukcji kulturowej i ideologicznej.

Lęk może być używany zarówno w sytuacji kształtowania obawy mającej racjonalne podstawy - co najczęściej bywa nazywane strachem - jak i lęku niemającego tych podstaw, a więc nieukierunkowanej obawy. Lęk przedmiotowy w przeciwieństwie do lęku bezprzedmiotowego musi być poprzedzony percepcją przedmiotu zagrożenia (Kępiński, 1977, s. 240). Kluczowym dla zrozumienia intensyfikacji lęku jako mechanizmu socjotechniki jest dostrzeżenie możliwości wywierania - dzięki niemu - wpływu społecznego. Systemy sterujące uruchamiające ten mechanizm pragną bowiem osiągnąć cel znacznie bardziej konkretny niż pobudzenie lękowe. Może być to uległość i pokora - jak w przypadku instytucji wyznaniowych, akceptacja funkcjonalnych dla systemu społecznego celów, posłuszeństwo i podporządkowanie władzy, strach i gotowość do walki z czynnikami wywołującymi go np. w działaniach marketingu społecznego, czy wzbudzenie zainteresowania odbiorców środków masowego przekazu, walczących o dobrą pozycję rynkową.

W każdym z wymienionych przypadków chodzi o preparację systemu sterowanego do większej podatności na wpływ. Nie lęk jest bowiem celem, lecz to, jakie postawy (lub tylko zachowania) można uzyskać dzięki jego wzmacnianiu. Każdy system społeczny jest zainteresowany wykorzystywaniem takich mechanizmów, które generują postawy funkcjonalne wobec niego. Ich pierwotną przesłanką może być pobudzenie lękowe. Nie ma wątpliwości, iż system demokracji liberalnej uzyskał znaczące efekty w tym procesie, choć zjawiska społeczne zachodzące w drugiej dekadzie XXI wieku jego efektywność wystawiają na poważną próbę. Obniżenie rangi wartości leżących u podstaw tego systemu (wolność i prawa jednostki, tolerancja, kształtowanie konsensusu społecznego, budowanie społeczeństwa obywatelskiego itd.) może zapowiadać czas nadejścia historycznego resetu, co oznacza niebezpieczeństwo globalnego konfliktu i kolejną wielką tragedię ludzkości.

Socjotechnika opierająca się na intensyfikacji lęku jest jednym z najstarszych sposobów podporządkowywania sobie ludzi. Wywoływanie strachu czy poczucia zagrożenia było i jest skuteczne w każdym systemie społecznym, chociaż w warunkach demokratycznych jest pozornie bardziej ograniczone, a w gruncie rzeczy głębiej ukryte w przekazach socjalizacyjnych. Można wręcz powiedzieć, iż mechanizmy socjotechniczne związane z kontrolą programującą i dyscyplinowaniem, w systemach demokratycznych muszą być częściej wykorzystywane, niż w systemach, w których władza nie pragnie tworzyć złudzeń wolności i opiera się na kontroli represyjnej. Do czasów, w których można było w celach socjotechnicznych rozpocząć wykorzystywanie mediów masowych, jednym z najstarszych sposobów wymuszania posłuszeństwa przez pobudzanie lęku było stosowanie kaźni, o czym szeroko pisał Michel Foucault (Foucault, 1998). 
Głównym adresatem kaźni nie była jej bezpośrednio poddana ofiara, lecz audytorium obserwujące widowisko okrutnego karania. Kaźń miała być jak najbardziej widoczna i w ogromie swych możliwości przerażająca. W ceremonii karania stroną nie mniej ważną od skazanego był lud, dla którego ów spektakl był odtwarzany. Skryta kaźń nie pełniłaby swej funkcji odstraszającej, nie przekazywałaby tej najważniejszej informacji, iż najmniejsze pogwałcenie prawa musi spotkać się z niezwykle surową karą Pana. Władza miała być w sposób widoczny przerażająca, co stanowiło wykorzystywanie mechanizmu intensyfikacji lęku.

Warto zauważyć, iż tę historycznie ukształtowaną formułę odstraszania współcześnie przejęło prawo w swym aspekcie prewencyjnym. Społeczne upowszechnianie wiedzy o prawie skupia się na jego elemencie represyjnym, co znakomicie sprzyja intensyfikacji lęku (Pawełczyk, 2001). W efekcie traktowania kary przede wszystkim jako formy odstraszania, pojawiają się poglądy sprzyjające dążeniom do zwiększania represyjności prawa wobec przestępców. W każdym kraju można zapewne znaleźć zwolenników poglądu, iż skoro aparat przymusu nie jest w stanie ująć wszystkich łamiących prawo, a poziom przestępczości rośnie, to tym, których uda się postawić przed sądem i udowodnić winę, należy wymierzyć karę odstraszającą swą surowością. Zgodnie z takim stanowiskiem nie nieuchronność kary za popełnione przewinienie, lecz jej zalegalizowane okrucieństwo - cecha kaźni - powinno odstraszać od łamania norm prawnych ${ }^{3}$.

We współczesnych systemach demokracji liberalnej władza przestaje być widoczna, ulegając rozproszeniu w sieci oddziaływania. Dyscyplinowanie społeczeństwa w oparciu o mechanizm intensyfikacji lęku musi jednak uwzględniać poważną trudność, jaką stanowi utrzymywanie odpowiedniego poziomu jego pobudzenia. Na tyle niskiego, aby pozwolił jednostkom i grupom na skuteczne działanie oraz na tyle wysokiego, aby polecenia systemu sterującego były bez oporu wykonywane. Stąd Benjamin Barber, opisując zachowanie społeczeństwa amerykańskiego, kierowanego strachem przed terrorystami, zwraca uwagę na stopniowalność pobudzenia lękowego, którego poziom zakodowany jest w kolory - żółty, pomarańczowy i czerwony alarm (Barber, 2004, s. 45). Poziom pobudzenia lękowego musi także ulegać zmianie bowiem do życia w strachu i lęku można się przyzwyczaić, co znakomicie opisał Erich Maria Remarque w swej powieści $\mathrm{Na}$ zachodzie bez zmian.

\section{Sterowanie lękiem a logika medialna}

Proces reprodukcji lęku musi trwać, stąd odnajdujemy w nim wciąż nowe wykreowane zagrożenia i niebezpieczeństwa. Fala terroryzmu wypiera przestępczość nieletnich i sama zanika pod wpływem obawy przed nowymi chorobami, za którą podąża lęk przed skażeniem środowiska, które goni kryzys ekonomiczny, wyprzedzany przez strach o ochronę danych osobowych itd. We współczesnej Kulturze Zachodu mechanizm intensyfikacji lęku uruchamiany jest przede wszystkim w procesie komunikowania masowego. Środki masowego przekazu zaszczepiają w nas lęk niezbędny dla prawidłowego funkcjonowania systemu. Media stoją na straży normy, skupiając się na szerokim

${ }^{3}$ W skali mikro mamy jednak także odstraszające tablice z napisem Kontrola radarowa czy - przerażające kierowców jeszcze w minionej dekadzie - atrapy policyjnych radiowozów. 
informowaniu społeczeństwa o zagrożeniach i represjach oczekujących na tych, którzy zachowują się niezgodnie ze społecznie usankcjonowanymi dyrektywami obrony (szczepionki, zakaz palenia tytoniu itp.). Środki masowego przekazu propagują wizję rzeczywistości, w której źródłem zagrożeń są nie tylko zjawiska obecne, ale także antycypowane (np. masowa inwigilacja elektroniczna), co ogromie rozszerza zbiór możliwych stymulatorów lęku. Medialny obraz świata jest niekończącą się serią tragedii, sensacji, skandali, a także zagrożeń, które niesie przyszłość. Zwłaszcza polityka przypomina arenę ścierania się dobra ze złem, co uzasadnia wojenną metaforykę stosowaną do jej opisu. Komunikaty związane z lękiem przed niedookreślonym - bądź strachem przed konkretnym - niebezpieczeństwem, szybciej zyskują zainteresowanie społeczeństwa, co oczywiście determinuje lepszą pozycję rynkową mediów. Pobudzenie lękowe jest efektem obowiązującego dyskursu emocjonalnego, zwłaszcza w obszarze polityki. Jesteśmy zasypywani setkami informacji, pokazujących beznadziejną sytuację jednostki w konfrontacji z wszechmocnymi instytucjami systemu i stosowanym przez nie przymusem. Jak zauważa Robert Grochowski „Przewrotność przekazu polega na tym, że autorzy tekstów i programów stają po stronie obywatela. Na dodatek ich intencje są szczere" (Grochowski, 2016, s. 140). Odbiorcy otrzymują jednak lekcje pokory, lęku i niemożności. Środki masowego przekazu po części nieświadomie uczestniczą więc w skutecznym zarządzaniu lękiem. „We współczesnych czasach działalność mediów można porównać do rozsiewania szkodliwego oprogramowania. Wystarczy, że media poinformują nas o zbliżającym się kryzysie - realnym czy nie, uruchamiają się reakcje mające ochronić nas przed zagrożeniem" (Ibidem, s. 141). Nie jesteśmy w stanie zweryfikować - a nawet racjonalnie przeanalizować - dostarczanych informacji. Żyjemy w świecie medialnie wytworzonego lęku, który ma nas uzależniać od aktualnych celów systemu.

Wykorzystywanie mechanizmu intensyfikacji lęku uznano za sposób walki z terroryzmem, umownie „nowymi” chorobami, skażeniem środowiska, zjawiskami nietolerancji, odradzaniem się nazizmu i wieloma innymi odchyleniami od funkcjonalnych dla systemu celów społecznych. Kwestia moralnej oceny działań i antropotechnicznego charakteru socjotechniki schodzi na drugi plan, wobec przekonania o wyższości celów i konieczności kształtowania prosystemowych postaw. W sferze politycznej przekonanie to stało się alternatywą wobec poszukiwania nowych idei i zachęcania do podążania za nimi, zastąpiło programy polityczne i realne propozycje ustrojowe. Co ciekawe, globalizacja mediów podważyła jedną z funkcji suwerennego państwa polegającą na monopolu kształtowania umysłów swoich obywateli. Możliwość dotarcia z medialnym przekazem do jednostek żyjących na każdej szerokości geograficznej ułatwia ponadnarodowe sterowanie bowiem można całemu światu pokazać oblicze zagrożeń, od kreowania strachu przed nowymi chorobami, nieokiełznaną falą uchodźców czy terroryzmem do ogólnego lęku przed wykluczeniem społecznym tych, którzy nie chcą mieścić się w mainstreamowym, konsumpcyjnym modelu życia. Riesmanowski człowiek zewnątrzsterowny (Riesman, 1996, s. 179-197), którego główną obawą w sferze relacji społecznych jest utrata akceptacji, stanowi prosty do sterowania obiekt, także za pomocą lęku. Mechanizm jego intensyfikacji charakteryzuje się w kulturze Zachodu uniwersalnymi cechami wykraczającymi poza funkcjonowanie konkretnych systemów społecznych. Lęk bowiem także podlega globalizacji. Media stanowią niezastąpiony instrument w propagowaniu pewnej wizji rzeczywistości, która stanowi przychylne tło do działań systemu sterującego. Ko- 
munikowanie masowe wpisuje się $\mathrm{w}$ działanie przymusu programującego - modelującego postawy, co stanowi podstawę socjotechniki dyscyplinowania.

W obecnej rzeczywistości istnieje wiele źródeł lęku wykorzystywanych przez system sterujący, ale tym, które w XXI wieku najbardziej poruszyło wyobraźnię społeczeństw w Kulturze Zachodu i które może ono poddać personifikacji jest terroryzm. Symbolem źródła lęku, które ma przynajmniej częściowo racjonalne podstawy, jest jednak nie tylko zjawisko terroryzmu i wiązane z nim penetrowanie świata chrześcijańskiego przez islam. Relacje międzynarodowe przedstawiane w środkach masowego przekazu są bowiem coraz częściej przedstawiane jako obszar wojny lub przynajmniej zagrożenia nią, co po ćwierćwieczu względnie stabilnej wizji świata staje się tym bardziej niepokojące. W masowych komunikatorach pojawiają się symbole politycznego zła, destrukcji, bezładu, mające budzić strach. „Postać wroga symbolizuje z reguły wszystkie wartości odwrócone, wróg jest ucieleśnieniem zła. Walka $\mathrm{z}$ wrogiem nie jest pojmowana jako gra o pewną stawkę, wróg nie jest kontrpartnerem czy rywalem, ale uosobieniem destrukcyjnych potęg, które niosą światu zagładę" (Filipowicz, 1988, s. 187/188).

W oddziaływaniach socjotechnicznych w skali mikro lęk ukierunkowany można pobudzać i utrwalać za pomocą różnych technik zależnych od konkretnych uwarunkowań społecznych, w tym zmiennych czynników wynikających z kondycji gospodarczej, sytuacji międzynarodowej czy aktualnych problemów zajmujących opinię publiczną. Odwoływanie się do poczucia zagrożenia, czy wręcz wywoływanie go, odnajdujemy w programach partii i kandydatów politycznych, pragnących sytuować siebie jako gwarantów walki z niebezpieczeństwami. Wykorzystywane faktyczne czy wykreowane zagrożenia mają nie tylko stanowić prosty klucz do uaktywniania emocji wyborców, lecz także ukrywać płycizny programowe podmiotów politycznych. Właściwy wybór ma stanowić szansę na oddalenie niebezpieczeństwa i redukcję poczucia lęku, bez wchodzenia w skomplikowane analizy przyczyn jego powstawania, a ułatwiać ma to strywializowany przekaz medialny.

\section{Lęk a utrata poczucia bezpieczeństwa}

O mechanizmie intensyfikacji lęku w skali makro pisał Zygmunt Bauman w Spoteczeństwie $w$ stanie oblężenia zauważając, iż o ogromie zagrożeń związanych z bezpieczeństwem osobistym trzeba ludziom wciąż przypominać, odmalowując je w najczarniejszych barwach, aby niespełnianie się obaw można było uznać za zdarzenie nadzwyczajne, za efekt czujności, troski i dobrej woli władzy lub w ogóle instytucji państwa (Bauman, 2006). Im bardziej lęk okazuje się bezzasadny, tym lepiej świadczy to o skuteczności działań obronnych, podejmowanych przez system sterujący. Władza już nie przeraża swą widocznością jak w opisywanych przez Michela Foucaulta czasach kaźni, ona broni przed tym co przeraża.

Inaczej wygląda sytuacja, jeśli chodzi o poczucie bezpieczeństwa socjalnego. Miał je zapewnić urzeczywistniany w drugiej połowie XX wieku neoliberalny projekt rozwoju społeczeństwa. Claus Offe wskazywał, iż społeczny, ekonomiczny i polityczny porządek został zbudowany w końcu lat 40. i na początku 50. wokół szerokiego consensusu - koncepcji państwa dobrobytu, która nie była podważana przez jakąkolwiek znaczącą siłę polityczną. Ta ugoda ustrojowa była także sankcjonowana i wzmacniana 
przez międzynarodową konfigurację sił, jaka wyłoniła się po II wojnie światowej (Offe, 1995, s. 227). Ów porządek był swoistą synergią pomiędzy demokracją a kapitalizmem, w którym ograniczeniom podlegała zarówno demokracja, jak i sam kapitalizm. W wyniku demokratyzacji większości instytucji społecznych, welfare state charakteryzowało się względnie płaską strukturą dochodów, która umożliwiała szerokiej rzeszy społeczeństwa uczestnictwo w sukcesach wzrostu gospodarczego (Łukasik, 2006, s. 79). „Ukryte socjologiczne założenie, leżące u podstaw ustrojowej organizacji państwa dobrobytu mówiło, iż wzory życia skoncentrowane wokół «prywatności», a więc rodziny, pracy i konsumpcji, absorbują energię i aspiracje większości obywateli” (Offe, 1995, s. 228). Jednostka miała być racjonalną maszyną tworzącą PKB, wobec tego uczestnictwo w konflikcie wokół polityki państwa stanowiłoby przedmiot tylko marginalnego zainteresowania większości społeczeństwa. Welfare state charakteryzowało ukierunkowanie sterowania społeczeństwem na „dążenie do", które oparte było na mechanizmie potęgowania potrzeb nieelementarnych, powodującym, iż jednostki przestają odróżniać potrzeby niezbędne do życia, od tych, których zaspokajanie wiąże się z akceptacją, prestiżem i pragnieniem przynależności do grupy kulturowej. Mechanizm ten odwoływał się przede wszystkim do potrzeby akceptacji, która mogła być zaspokajana poprzez uczestnictwo w wyścigu konsumpcyjnym. System sterujący wytworzył i rozpowszechniał ideologię konsumpcji, czyli starał się o to, aby najbardziej istotne kryteria wartości w społeczeństwie były tymi, które potęgują potrzeby ekspansji (Łukasik, 2006, s. 79). Jednocześnie jednak możliwość odebrania szansy uczestniczenia w tym wyścigu wzbudzać musiała lęk i strach przed wykluczeniem. Sukcesy ugrupowań populistycznych odnoszone w ostatnich latach w różnych państwach demokracji liberalnej wydają się potwierdzać hipotezę o utracie poczucia bezpieczeństwa socjalnego i wzroście możliwości sterowania społeczeństwem za pomocą mechanizmu intensyfikacji lęku. Dwudziestowieczny neoliberalny projekt pędzi ku samozniszczeniu bowiem brakuje w nim możliwości poszukiwania nowych rozwiązań pozwalających stworzyć społeczeństwo i wolne, i zasobne. Liberałowie stali się obecnie więźniami przeszłości, z którą nie potrafią się rozstać (Żakowski, 2017, s. 25). Społeczeństwa w stanie pobudzenia lęku związanego z przyszłością i perspektywami rozwoju godzą się na znaczące ograniczenia praw obywatelskich i osobistych. Akceptują odejście od zasad liberalnej demokracji licząc, że uzyskane w zamian świadczenia zwiększą ich poczucie bezpieczeństwa oraz pozwolą uczestniczyć w konsumpcyjnym wyścigu, w którym osiągnięte miejsce wciąż przekłada się na społeczne poczucie wartości. Populiści wcześniej dostrzegli lęk w sferze socjalnej i potrafili go wykorzystać. Wypowiedzi polityków liberalnych wyrażające żal ,jak mogliśmy tego nie zauważyć" wskazują jedynie definitywność ich przemijania. Niepokój może wzbudzać wniosek, iż konfrontację z populizmem wygra ten, kto lepiej będzie zarządzał lękiem.

\section{Podsumowanie}

Poziom lęku odczuwanego przez społeczeństwa państw, których systemy polityczne opierają się na zasadach liberalnej demokracji rośnie od początku XXI wieku. Częściowo odpowiadają za to obiektywne czynniki, które wystąpiły w ciągu ostatnich kilkuna- 
stu lat, jak zamachy terrorystyczne, związane głównie z ekstremistycznymi organizacjami islamskimi, narastająca fala uchodźców, kryzys ekonomiczny czy utrata poczucia bezpieczeństwa socjalnego. Samo wystąpienie tych zjawisk nie tłumaczy jednak wykorzystywania mechanizmu intensyfikacji lęku zauważalnego w przekazach medialnych, inspirowanych często przez podmioty polityczne. Uważam, iż socjotechniczna zasada, zgodnie z którą system sterowany utrzymywany w stanie pobudzenia lękowego jest bardziej podatny na wpływ nabiera współcześnie nowego wymiaru m.in. ze względu na niespójność celów reprodukcji porządku społecznego. Zwiększa to jeszcze bardziej rolę środków masowego przekazu, które mechanizm intensyfikacji lęku wykorzystują kierując się własnymi interesami rynkowymi. Być może - paradoksalnie - w nowoczesnych warunkach komunikacyjnych zwiastuje to powrót do czasów przednowoczesnych i formuły, która wówczas odzwierciedlała rzeczywistą podmiotowość jednostki - Błogosławiony, kto się boi Pana. Błogosławiony jest każdy, kto się boi Pana i chodzi Jego drogami.

\section{Bibliografia}

Barber B. (2004), Imperium strachu. Wojna, terroryzm i demokracja, Warszawa.

Bauman Z. (2006), Społeczeństwo w stanie oblężenia, Warszawa.

Debord G. (1998), Społeczeństwo spektaklu, Gdańsk.

Filipowicz S. (1988), Mit i spektakl władzy, Warszawa.

Foucault M. (1998), Nadzorować i karać, Warszawa.

Grochowski R. (2016), Lęk w telewizyjnych obrazach rzeczywistości, w: Socjotechnika lęku w polityce, red. F. Pierzchalski, J. Golimowski, Bydgoszcz.

Kępiński A. (1977), Lęk, Warszawa.

Luhmann N. (2007), Systemy społeczne, Kraków.

Łukasik M. (2006), Mechanizm intensyfikacji lęku w socjotechnice wspótczesnej demokracji, w: Dwa oblicza socjotechniki, red. P. Pawełczyk, Poznań.

Montaigne de M. (1985), Próby, t. I, Warszawa.

Offe C. (1995), Nowe ruchy spoleczne, w: Wtadza i spoleczeństwo, wyb. i opr. J. Szczupaczyński, Warszawa.

Pawełczyk P. (2000), Socjotechniczne aspekty gry politycznej, Poznań.

Pawełczyk P. (2001), Socjotechnika przymusu, „Zeszyty Naukowe” Wyższej Szkoły Zarządzania i Marketingu, nr 1, Warszawa.

Porębski L. (2016), Polityka jako zarządzanie zagrożeniem. Psychologiczne podstawy wykorzystania lęku w życiu publicznym, w: Socjotechnika lęku w polityce, red. F. Pierzchalski, J. Golimowski, Bydgoszcz.

Riesman D. (1996), Samotny ttum, Warszawa.

Wieczorek-Orlikowska J. (2016), Lęk jako wyznacznik współczesności-determinanty indywidualne i systemowe, w: Socjotechnika lęku w polityce, red. F. Pierzchalski, J. Golimowski, Bydgoszcz 2016.

Żakowski J. (2017), Mania nicniezmieniania, „Polityka”, nr 16. 


\title{
Social engineering of anxiety - the application in the 21 st century
}

\begin{abstract}
Summary
Human control the masses by means of shaping the level of anxiety is known for thousands of years. The change over the last anxiety promoters decades does not mean a departure from the fundamental principle of social engineering speaking, that controlled system maintained in the state boost general anxiety is more susceptible to influence. Today, the mass media, which function in the conditions of globalization is part of the media logic, that the mechanism of use more efficiently than ever before. At the same time contribute one - probably only partly consciously - characteristic for social engineering the process of the reproduction of the social order, which targets are determined by the interests of the social system.

The main objective of the considerations presented in the article is to indicate the timeliness of the application of the intensifying anxiety as a mechanism to subjugate the people. The author tries to answer two questions. First, why in spite of the development of democratic forms of governance be an effective way to influence and, second, why the modern mass media so eager to participate in these activities? The conclusions from the analysis indicate that the social engineering principle, according to which the system controlled maintained able to stimulate general anxiety is more vulnerable to the impact of the gains today, a new dimension because of the inconsistencies of the purpose of the reproduction of social order. This increases even more the role of the mass media, that the mechanism of intensifying anxiety use driven by their own interests. The article has a theoretical nature, is based on a critical analysis of social engineering and praxeology publications and illustrations cases of the application of the social engineering tactics of fear in the 21 st century.
\end{abstract}

Key words: anxiety, social engineering, media logic 
